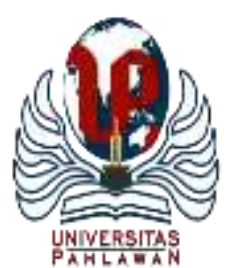

Edukatif : Jurnal Ilmu Pendidikan Volume 4 Nomor 1 Tahun 2022 Halm 1307 - 1314

EDUKATIF: JURNAL ILMU PENDIDIKAN

Research \& Learning in Education

https://edukatif.org/index.php/edukatif/index

\section{Manajemen Pengembangan Bahasa Arab di Madrasah Tsanawiyah}

\author{
Muhammad Rizki Dermawan Saragih ${ }^{1 凶}$, Faisal $^{2}$, Neliwati ${ }^{3}$
}

Universitas Islam Negeri Sumatera Utara Medan, Indonesia ${ }^{1,2,3}$

E-mail : $\underline{\text { rizkisaragih19@gmail.com }}{ }^{1}, \underline{\text { rasyaibnfaishal@gmail.com }}^{2}, \underline{\text { neliwati@uinsu.ac.id }}^{3}$

\begin{abstract}
Abstrak
Penelitian ini bertujuan untuk mendeskripsikan manajemen pengembangan pembelajaran bahasa Arab di MTs Swasta Kesuma LKMD Namorambe. Fokus kajian ini juga berkaitan dengan subjek dan objek dari manajemen pembelajaran, yaitu kepala madrasah, guru, tenaga kependidikan, dan peserta didik. Metode penelitian yang digunakan yaitu penelitian jenis kualitatif. Adapun temuan yang didapatkan setelah melaksanakan penelitian ini adalah manajemen pengembangan bahasa Arab di Madrasah Tsanawiyah Kusuma LKMD Namorambe dengan mengikuti peraturan pemerintah, yaitu (1) tiga les dalam sepekan serta melatih dan meningkatkan kompetensi guru yang berkompeten di bidangnya, (2) target pencapaian yang diharapkan setelah anak-anak mempelajari Bahasa Arab di kelas selama 2 tahun mereka mampu berbahasa Arab, (3) Strategi yang dipilih kepala Madrasah untuk mengembangkan Bahasa Arab di lingkungan Madrasah Tsanawiyah Kesuma LKMD Namorambe ini adalah dengan Memilih guru yang mengajar mata pelajaran Bahasa Arab yang profesional, memberikan motivasi serta melakukan evaluasi pembaharuan yang dibutuhkan terkait pengembangan Bahasa Arab.
\end{abstract}

Kata Kunci: Manajemen, Pembelajaran, Pengembangan Bahasa Arab.

\begin{abstract}
This study aims to describe the management of Arabic learning development at MTs Swasta Kesuma LKMD Namorambe. The focus of this study is also related to the subject and object of learning management, namely madrasa principals, teachers, education staff, and students. The research method used is a qualitative type of research. The findings obtained after carrying out this research are the management of Arabic language development at Madrasah Tsanawiyah Kusuma LKMD Namorambe by following government regulations, namely (1) three lessons a week and training and improving the competence of teachers who are competent in their fields, (2) the expected achievement targets after the children have studied Arabic in class for 2 years they are able to speak Arabic, (3) The strategy chosen by the head of the Madrasa to develop Arabic in the Madrasah Tsanawiyah Kesuma LKMD Namorambe environment is to choose a teacher who teaches Arabic subjects professionally, provide motivation and evaluate the necessary reforms related to the development of the Arabic language.
\end{abstract}

Keywords: Management, Learning, Development of Arabic Language.

Copyright (c) 2022 Muhammad Rizki Dermawan Saragih, Faisal, Neliwati

$\triangle$ Corresponding author:

Email : rizkisaragih19@gmail.com

DOI : https://doi.org/10.31004/edukatif.v4i1.2162

ISSN 2656-8063 (Media Cetak)

ISSN 2656-8071 (Media Online)

Edukatif : Jurnal Ilmu Pendidikan Vol 4 No 1 Tahun 2022

p-ISSN 2656-8063 e-ISSN 2656-8071 
1308 Manajemen Pengembangan Bahasa Arab di Madrasah Tsanawiyah - Muhammad Rizki Dermawan Saragih, Faisal, Neliwati

DOI: https://doi.org/10.31004/edukatif.v4i1.2162

\section{PENDAHULUAN}

Lembaga pendidikan sangatlah "menjamur" di Negara Kesatuan Republik Indonesia (NKRI) (Bafadhol, 2017:14). Dari sekian banyak lembaga pendidikan tersebut, lembaga pendidikan Islam juga merebak dan ikut serta dalam berperan untuk ikut serta dalam mencerdaskan kehidupan bangsa. Hal ini menunjukkan bahwa lembaga pendidikan Islam di Indonesia telah mengalami perkembangan pesat (Rahman, 2018:1-14).

Lembaga Pendidikan Islam memiliki berbagai tujuan, salah satunya, yaitu untuk mengajarkan nilai-nilai Islam melalui pendidikan tersistem (Akhiruddin, 2015:195-219). Dari sekian banyak nilai serta pelajaran pelajaran Islam tersebut, mata pelajaran serta kemampuan peserta didik terkait Bahasa Arab sangatlah penting (Setyawan \& Anwar, 2020:11-19). Hal tersebut dikarenakan Al-Qur'an dan Hadis yang merupakan sumber rujukan Agama Islam turun dan sampai dengan Bahasa Arab (Pane, 2018; Aprizal, 2021).

Madrasah Tsanawiyah Swasta Kesuma LKMD Namorambe merupakan salah satu madrasah yang mengajarkan bahasa Arab setiap tingkatannya. Dengan demikan, harapannya adalah setelah mereka belajar 2 tahun seharusnya sudah mampu berbahasa Arab. Namun hal itu, masih belum terjadi. Menurut Munir (2018:27-35), pembelajaran bahasa Arab secara kuantitas sudah cukup, akan tetapi kebanyakan kualitas pembelajaran belum optimal terhadap kemampuan (keterampilan) bahasa Arab peserta didik.

Sejatinya, kajian tentang manajemen pengembangan pembelajaran bahasa Arab telah diteliti dari berbagai aspek oleh peneliti terdahulu. Di antaranya membahas dari aspek pendekatan manajemen berbasis sekolah (Thoha, 2012), manajemen program pelatihan dan pengembangan bahasa Arab (Manshur, 2015), strategi pengelolaan komponen pembelajaran bahasa Arab (Rohman, 2014), manajemen perencanaan pembelajaran berbasis kurikulum 2013 (Ninoersy, et.al., 2019:83-102), manajemen pengembangan kemampuan bahasa Arab siswa (Munief, et.al., 2021:1563-1571), serta aspek kajian teori dan praktik (kontekstualisasi) manajemen pengembangan bahasa Arab (Nurcholis, 2015; Wijaya, 2017:1-18).

Mencermati literature review di atas, diketahui bahwa terdapat "ruang kosong" kajian manajemen pengembangan pembelajaran bahasa Arab yaitu dari aspek pengelolaan kegiatan, strategi pengembangan, pelatihan, penetapan target dan keselarasan pengembangan dengan peraturan yang ditetapkan pemerintah. Atas dasar ini, peneliti secara mendalam mengkaji aspek tersebut, yang dirangkum dalam judul penelitian, "Manajemen Pengembangan Pembelajaran Bahasa Arab di Madrasah Tsanawiyah Swasta Kesuma LKMD Namorambe".

\section{METODE PENELITIAN}

Penelitian ini dilaksanakan di MTsS Kesuma LKMD Namorambe. Jenis penelitian yang digunakan ialah pendekatan kualitatif metode deskriptif (Assingkily, 2021). Dikatakan sebagai penelitian deskriptif, sebab penelitian ini mengulas tema dan temuan riset dalam bentuk narasi kalimat dan gambar, bukan terfokus pada angka-angka. Penelitian ini fokus mengkaji manajemen pengembangan bahasa Arab di madrasah tersebut. Informan penelitian ini meliputi kepala madrasah, wakil kepala madrasah bidang kurikulum, guru mata pelajaran bahasa Arab, dan siswa di MTsS Kesuma LKMD Namorambe. Pemerolehan data menggunakan 3 teknik, yaitu pertama, wawancara. Teknik dilaksanakan secara langsung antara peneliti dengan informan, di mana peneliti sudah mempersiapkan pertanyaan-pertanyaan sebagai pedoman wawancara. Kedua, observasi. Adapun teknik ini dimaksudkan untuk melihat langsung proses manajemen pengembangan bahasa Arab di madrasah tersebut. Ketiga, dokumentasi, yaitu teknik yang dilaksanakan dengan mengkaji dokumen atau arsip madrasah untuk melihat kesesuaian antar data. Selanjutnya, data dianalisa menggunakan teknik reduksi data, penyajian data, dan penarikan kesimpulan. Akhirnya, keabsahan suatu data diperoleh melalui uji teknik triangulasi data. 
1309 Manajemen Pengembangan Bahasa Arab di Madrasah Tsanawiyah - Muhammad Rizki Dermawan Saragih, Faisal, Neliwati

DOI: https://doi.org/10.31004/edukatif.v4i1.2162

\section{HASIL DAN PEMBAHASAN PENELITIAN}

Manajemen merupakan kata yang berasal dari bahasa Latin yaitu "mantis" yang berarti tangan dan "agree" berarti melakukan. Keduanya digabung menjadi "manager" yang berarti menangani (Ahmad, 2019), yaitu menangani berbagai persoalan atau permasalahan yang ada dalam suatu organisasi, maupun lembaga kependidikan. Rachman (2015) mengatakan, manajemen adalah suatu kegiatan mengatur yang organisasi, perusahaan, maupun lembaga yang dilakukan oleh manajer. Dengan demikian, manajer bertugas sebagai puncak pimpinan sekaligus pengatur utama dalam suatu kelembagaan/organisasi.

Lebih lanjut, Syafaruddin (2015) mengatakan manajemen merupakan sekumpulan unsur, struktur dan semua komponen terkait untuk mencapai tujuan yang sudah dirancang dan ditentukan tentunya melalui orangorang yang saling bekerjasama dalam mewujudkan sistem dan prosedur yang telah dibangun. Ini menunjukkan holistiknya implementasi manajemen dalam suatu lembaga, termasuk lembaga pendidikan. Bahkan, orientasi pendidikan berbanding lurus dengan pelaksanaan fungsi-fungsi manajemen, meliputi perencanaan, pengorganisasian, pengarahan, pengawasan dan penilaian. Suksesnya implementasi fungsifungsi manajemen tersebut, akan sejalan pula dengan ketercapaian optimal suatu lembaga pendidikan.

Definisi di atas, menguatkan apa yang pernah disampaikan oleh Kamaluddin, et.al. (2010) bahwa manajemen itu adalah seni mengatur dan juga melaksanakan. Lebih lanjut, manajemen memiliki fungsi, yaitu: a) Planning/perencanaan merupakan suatu proses awal untuk suatu tujuan tertentu dengan menentukan terlebih dahulu proses apa yang harus dilakukan agar tujuan tersebut terpenuhi, tentunya tahap ini disusun secara sistematis, terjadwal, terukur dan terarah melalui program-program kerja, b) Organizing/ Pengorganisasian adalah proses penyusunan tugas, kerja serta tanggung jawab, istilah lainnya sering disebut dengan job description yaitu penjabaran tentang bagaimana individu ditempatkan, tugas dan wewenang kerja, serta sanksi dan akuntabilitas dari suatu pekerjaan, c) Actuating/Penggerakan adalah memberikan perintah, petunjuk, pedoman dan nasehat serta keterampilan dalam berkomunikasi, kesemuaannya ini berfungsi sebagai aturan atau role dari kegiatan manajemen, harapannya dapat terlaksana semua kegiatan sesuai dengan kerangka acuan bersama yang telah ditetapkan secara konsensus, dan; d) Controlling adalah proses untuk memastikan bahwa aktivitas yang dilaksanakan benar sesuai apa tidak dengan perencanaan sebelumnya (Mesiono, 2020; Winoto, 2020; Siagian, 1997; Hidayat, 2017).

Sejatinya, seluruh komponen dalam pendidikan membutuhkan manajemen untuk optimalisasi pencapaian tujuan pendidikan, termasuk dalam aspek pembelajaran. Dalam penelitian ini, dikaji manajemen pembelajaran dalam mata pelajaran bahasa Arab. Mulai dari aspek perencanaan, pelaksanaan, pengarahan dan pengawasan pembelajaran bahasa Arab. Dengan demikian, pembelajaran bahasa Arab yang dilaksanakan di MTsS Kesuma LKMD Naorambe dapat terlaksana dengan efektif dan efisien.

Adapun pembelajaran bahasa Arab merupakan kata yang terdiri dari tiga kata, yaitu pembelajaran, bahasa, dan Arab. Namun, untuk memahami defenisi ini penjabaran yang diperlukan hanya "pembelajaran" dan "Bahasa". Pembelajaran menurut Pane \& Dasopang (2017) adalah proses transferisasi ilmu dan pengetahuan terhadap peserta didik. Dalam prosesnya, transferisasi ini akan optimal bila dilakukan sesuai dengan konsep tata kelola atau manajemen yang efektif. Sedangkan bahasa, menurut Oktarizka, et.al. (2018) adalah bunyi-bunyi yang dengannya manusia menyampaikan apa yang ingin dia sampaikan, lebih lanjut bahasa juga alat komunikasi antar individu. Bahasa juga terdiri dari beberapa aspek, mulai dari bahasa daerah, bahasa nasional, hingga bahasa internasional. Dengan demikian, dapat disimpulkan bahwa pembelajaran bahasa Arab adalah proses transferisasi ilmu dan pengetahuan terkait Bahasa Arab terhadap peserta didik sebagai alat komunikasi dan pembelajaran salah satu bahasa asing di lingkungan sekolah atau madrasah.

Sejatinya, metode pembelajaran variatif secara kuantitas, mulai dari metode inkuiri, discovery, dan lain sebagainya. Begitupun, dari aspek kualitas, seluruh metode nilainya sama, tinggal lagi bagaimana pendidik mengamati situasi kelas dan suasana pembelajaran, guna menerapkan metode yang tepat bagi pembelajaran. Sebab, satu mata pelajaran dengan berbagai materi ajar di dalamnya, akan monoton bila hanya satu metode 
1310 Manajemen Pengembangan Bahasa Arab di Madrasah Tsanawiyah - Muhammad Rizki Dermawan Saragih, Faisal, Neliwati

DOI: https://doi.org/10.31004/edukatif.v4i1.2162

yang digunakan. Untuk itu, dibutuhkan kreativitas pendidik dalam penerapan berbagai metode pembelajaran sesuai dengan materi dan suasana pembelajaran.

Sebelum membahas metode yang tepat dalam pembelajaran bahasa Arab, perlu dimengerti hakikat atau makna dari metode. Metode adalah kumpulan step atau kumpulan langkah-langkah yang dilakukan untuk terselesaikannya sesuatu yang diinginkan (Harahap, 2018:13-20). Artinya, metode adalah jalur yang harus ditempuh sebagai jalan penyampaian proses pembelajaran secara efektif. Apabila guru menerapkan metode yang bersifat monoton, tentu akan menghadirkan rasa jenuh bagi siswa selama proses pembelajaran, sebaliknya bila guru mampu menerapkan metode secara kreatif, akan menghadirkan suasana pembelajaran yang menyenangkan dan bermakna bagi seluruh siswa.

Dalam pembelajaran Bahasa Arab, terdapat beberapa metode pembelajarannya (Al-Fawzan, 2015), berikut ini metode tersebut; Pertama Metode Qowaid dan Terjemah: Ini adalah salah satu metode tertua yang digunakan dalam pengajaran bahasa asing. Metode ini membuat tujuan pertamanya untuk mengajarkan aturan bahasa asing, dan mendorong siswa untuk menghafal dan menghafalnya, dan bahasa tersebut diajarkan melalui terjemahan antara dua bahasa: ibu dan bahasa asing, dan metode ini berkaitan dengan pengembangan kemampuan peserta didik dalam keterampilan membaca dan menulis dalam bahasa asing. Diambil dari metode tata bahasa dan terjemahan yang mengabaikan keterampilan mendengarkan dan berbicara, yang merupakan dasar dari bahasa, melalui metode ini peserta didik akan didekatkan dengan pemahaman bahasa asing melalui perihal yang mudah untuk dihafal oleh siswa.

Kedua, Metode Mubanyir: Metode ini berkaitan dengan aspek lisan bahasa, tidak seperti metode tata bahasa dan terjemahan, dan mencegah bahasa perantara, apa pun alasannya, dan tidak memberikan siswa dengan aturan tata bahasa teoritis, dan itu cukup untuk melatihnya pada pola dan struktur bahasa, dan menghubungkan langsung antara kata dan hal yang ditunjukkannya, dan menggunakan metode imitasi dan menghafal, sampai dihafal Siswa membuat banyak kalimat dalam bahasa asing. Diambil dari metode ini yang berfokus pada sisi lisan bahasa (menyimak dan berbicara) dan mengabaikan sisi tertulis dari bahasa (membaca dan menulis), dan mengandalkan latihan stereotip, tanpa memberikan siswa beberapa ketentuan dan tata bahasa, aturan, menghalangi siswa untuk menyadari realitas tumpang tindih tata bahasa, dan aturan yang mengaturnya.

Ketiga, Metode Syamiyyah Syafahiyyah. Salah satu dasar terpenting dari metode ini adalah penggunaan alat bantu audio-visual yang ekstensif, dan penggunaan berbagai metode untuk pengajaran bahasa, seperti peniruan, pengulangan dan penghafalan, dan fokus pada metode pengukuran, sambil mengurangi penjelasannya, dan analisis gramatikal. Sebaliknya, siswa diberikan pelatihan terfokus dalam pola bahasa dan struktur tata bahasa. Dengan demikian, siswa tidak hanya dididik untuk menghafal kosakata dalam bahasa Arab, melainkan sudah belajar susunan gramatikal bahasanya, atau dikenal dengan istilah ilmu 'alat, berupa nahwu dan shorof.

Keempat, Metode Tawashuliyyah. Tujuan akhir dari metode ini adalah untuk membekali siswa dengan kemampuan menggunakan bahasa asing sebagai alat komunikasi, untuk mencapai berbagai tujuannya. Materi disajikan dengan cara ini, bukan atas dasar perkembangan linguistik, melainkan atas dasar kemajuan karir yang komunikatif. Pekerjaan tersebut dilakukan melalui berbagai kegiatan, di dalam satuan pendidikan. Metode pengajaran tergantung pada penciptaan situasi nyata dan realistis untuk penggunaan bahasa, seperti: menghadapi pertanyaan, bertukar informasi dan ide, merekam dan mengambil informasi, dan menggunakan keterampilan untuk memecahkan masalah, berdiskusi dan berpartisipasi. Dalam metode ini, peserta didik diberi pencerahan tentang pentingnya bahasa "asing", khususnya bahasa Arab bagi masa depan dan karir peserta didik. Hal ini didasarkan kepada penetapan bahasa Arab sebagai salah satu bahasa PBB, selanjutnya banyak kitab-kitab turats yang ditulis ulama-ulama terdahulu dalam bahasa Arab.

Kelima, Metode Intiqoiyyah. Mereka yang mengikuti metode ini percaya bahwa guru bebas untuk mengikuti metode yang sesuai dengan siswanya, dia berhak menggunakan cara ini, atau itu .Ia juga memiliki 


\section{Manajemen Pengembangan Bahasa Arab di Madrasah Tsanawiyah - Muhammad Rizki Dermawan Saragih, Faisal, Neliwati \\ DOI: https://doi.org/10.31004/edukatif.v4i1.2162}

hak untuk memilih dari metode-metode yang ia anggap cocok untuk situasi guru, karena ia dapat mengikuti salah satu metode tata bahasa dan metode terjemahan, ketika mengajar salah satu keterampilan bahasa, dan kemudian memilih salah satu metode. metode audio-oral dalam situasi lain. Filosofi metode ini berangkat dari kenyataan bahwa setiap metode memiliki kelebihan yang berguna dalam pengajaran bahasa, dan tidak ada metode ideal yang bebas dari kekurangan, dan metode pengajaran saling melengkapi dan tidak bertentangan, dan ada tidak ada metode yang sesuai dengan semua tujuan, siswa, guru dan program. Metode selektif datang untuk mendapatkan keuntungan dari keuntungan dari metode sebelumnya.

Hal penting lainnya adalah Kemahiran Bahasa Arab yang terdiri dari: pertama, Kemahiran Mendengar. Mendengarkan adalah salah satu keterampilan bahasa, yang tujuannya adalah pengetahuan terkait suara, pemahaman, dan penafsiran (Siddik, 2016). Keterampilan ini sangatlah dibutuhkan seseorang dalam kehidupannya. Karena, jika seorang anak tidak dapat mendengar maka iya juga dapat dipastikan tidak dapat berbicara. Apabila kedua hal ini terjadi pada anak, maka metode yang dapat dilakukan untuk mengajarinya adalah metode isyarat. Bahkan, telah disebutkan di dalam al-Qur'an bahwa potensi utama dalam diri manusia setelah dilahirkan dari rahim ibunya yaitu potensi pendengaran, kemudian potensi penglihatan dan potensi penghayatan. Atas dasar ini, keterampilan mendengar sangat penting bagi peserta didik dalam menindaklanjuti setiap pembelajaran yang diterimanya.

Kedua, Kemahiran Berbicara atau Maharotul Kalam. Keterampilan Berbicara adalah kemmapuan seseorang dalam mengungkapakan bunyi bunyi melalui lisan tentang apa apa yang ia inginkan baik ide, argumen, wawasan dan lain-lain (Hermawan, 2011). Tentunya keterampilan ini adalah keterampilan yang dapat dikuasai seseorang setelah dia menguasai keterampilan mendengar. Oleh karena itu, dalam memulai latihan berbicara haruslah menguasai kemahiran mendengar, kosakata dan juga keberanian dalam mengungkapkan yang diinginkan. Melatih peserta didik untuk terampil berbicara bukanlah sekadar pengajaran yang bersifat teoretis, sebagai keterampilan ini akan lebih terasah pada diri peserta didik melalui pelatihanpelatihan. Sebab, keterampilan ini juga berkaitan erat dengan mental anak untuk berani dan percaya diri mengungkapkan sesuatu melalui ucapan lisan.

Ketiga, Kemahiran Membaca. Membaca adalah salah satu keterampilan bahasa yang paling penting dipelajari orang. Seseorang membaca untuk berkomunikasi dengan orang lain, dan untuk mengetahui hal-hal yang diinginkan dan perlu diketahui (Turley, 2010). Daou (2011) mengatakan bahwa membaca adalah proses pengenalan terhadap kata-kata dan kalimat, kemudian mengarahkan pikiran untuk pemahaman, analisis, penilaian, dan pengaplikasian. Kemahiran ini sangat diperlukan bagi pengembangan intelektualitas peserta didik. Sebagai individu yang berstatus makhluk sosial, peserta didik harus mampu membaca teks yang diperlukan untuk perluasan atau pengembangan wawasan. Di samping itu, membaca di sini juga berkaitan dengan situasi atau keadaan yang berhubungan dengan proses pembelajaran di kelas maupun di luar kelas.

Keempat, Kemahiran Menulis. Menulis adalah penggunaan rumus rumus tertentu untuk mengungkapkan sesuatu dalam bentuk tulisan (Mahmood \& Zailani, 2017:20-27). Selanjutnya, Tarigan (2008) mengemukakan bahwa kemahiran menulis merupakan kemahiran yang paling akhir yang harus dimiliki seseorang setelah mengusai tiga kemahiran bahasa yang lainnya yaitu: mendengar, berbicara dan membaca. Menurut Iskandarwasid (2011) seorang penulis dalam mengungkapkan apa yang dia inginkan haruslah terampil dalam beberapa hal, di antaranya adalah terampil memilah milih gaya bahasa, penguasaan terhadap kosakata serta struktur dan pola penyusunan kalimat. Mencermati kemahiran ini sifatnya kumulatif, artinya berbagai kemahiran sebelumnya akan dapat teraktualisasikan melalui tulisan. Dengan demikian, siklus pembelajaran dasar akan kembali terulang. Di mana mereka yang mahir menulis akan men-sugesti pembaca untuk mahir keterampilan-keterampilan sebelumnya, mulai dari mendengarkan, berbicara dan membaca.

Adapun hasil dari penelitian ini adalah: pertama, manajemen pengembangan bahasa Arab di Madrasah Tsanawiyah Kesuma LKMD Namorambe tentunya perlu disampaikan bahwa Madrasah Tsanawiyah ini tidak lembaga pendidikan berupa pondok pesantren yang masyarakatnya menginap dan tinggal di asrama yang 
1312 Manajemen Pengembangan Bahasa Arab di Madrasah Tsanawiyah - Muhammad Rizki Dermawan Saragih, Faisal, Neliwati

DOI: https://doi.org/10.31004/edukatif.v4i1.2162

tentunya memiliki peraturan yang mengharuskan peserta didiknya untuk selalu berkomunikasi dengan Bahasa Arab. Adapun MTs Kesuma LKMD ini adalah madrasah yang sebagaimana pada umumnya masuk pagi dan pulang siang. Oleh karenanya pengajaran Bahasa Arab di madrasah ini mengikuti peraturan pemerintah yaitu 3 Les dalam sepekan. Meskipun demikian, karena pentingnya Bahasa Arab ini bagi generasi Islam ke depan, maka lembaga ini sangat memfokuskan dan memilihkan pendidik yang berkompeten di bidangnya.

Kedua, target pencapaian yang diharapkan setelah anak anak mempelajari Bahasa Arab di kelas selama 2 tahun adalah mereka mampu berbahasa Arab artinya bahwa mereka mampu berbicara dan berkomunikasi dengan Bahasa Arab dengan baik, mereka juga mampu memahami apa yang mereka dengar dengan berbahasa Arab baik memahami perkataan lawan bicaranya atau hanya sebatas mendengar voice atau dari film-film yang ditonton, film yang dimaksudkan tentu berbahasa Arab, mulai dari semula menggunakan subtitle hingga tanpa subtitle untuk melatih keterampilan anak dalam memahami dialog atau komunikasi dengan penutur asing. Diharapkan mereka juga mampu memahami apa yang dibaca serta mampu menuliskan apa yang ingin ia sampaikan. Dengan demikian, pembelajaran akan dipandang efektif secara praktikal, tidak hanya teori atau konsep yang belum terealisasikan.

Ketiga, strategi yang dipilih kepala madrasah untuk mengembangkan Bahasa Arab di lingkungan Madrasah Tsanawiyah Kusuma LKMD Namorambe ini adalah dengan berbagai macam staregi. Di antara strategi terkemuka adalah: (a) Memilih guru yang mengajar mata pelajaran bahasa Arab merupakan pendidik yang faham dan mampu berbahasa Arab secara aktif. Hal ini merupakan hal sangat penting. Sebab, pendidik sangatlah berpengaruh terhadap peserta didiknya. Setidaknya lahir pada hati mereka untuk lebih giat belajar bahasa Arab karena melihat pendidik sebagai suri tauladannya dalam berbahasa Arab, (b) Memberikan motivasi-motivasi yang membekas di hati para peserta didik untuk selalu semangat dan cinta dengan Bahasa Arab, dan (c) Melakukan evaluasi dan pembaharuan yang dibutuhkan terkait pengembangan bahasa Arab dengan berdiskusi dengan Guru Bahasa Arab dan mereka yang paham terkait pengajaran Bahasa Arab.

\section{KESIMPULAN}

Berdasarkan pemaparan temuan dan pembahasan di atas, diperoleh hasil tentang manajemen pengembangan bahasa Arab di MTsS Kesuma LKMD Namorambe, yang dibagi menjadi 3 (tiga) poin, yaitu (1) kurikulum mengacu pada pemerintah, yakni tiga les dalam sepekan serta melatih dan meningkatkan kompetensi guru yang berkompeten di bidangnya, (2) target pencapaian yang diharapkan setelah anak-anak mempelajari Bahasa Arab di kelas selama 2 tahun mereka mampu berbahasa Arab, (3) Strategi yang dipilih kepala Madrasah untuk mengembangkan Bahasa Arab di lingkungan Madrasah Tsanawiyah Kesuma LKMD Namorambe ini adalah dengan Memilih guru yang mengajar mata pelajaran Bahasa Arab yang profesional, memberikan motivasi serta melakukan evaluasi pembaharuan yang dibutuhkan terkait pengembangan Bahasa Arab.Hasil penelitian ini menunjukkan bahwa kepemimpinan kepala MIS Dinul Islam Hinai telah mencapai beberapa indikator keberhasilan kepemimpinan dalam sebuah organisasi yaitu pendelegasian wewenang yang luas, struktur organisasi sesuai dengan kebutuhan organisasi, semakin meningkatnya aktivitas-aktivitas manusiawi atau aspek sosial yang lebih human sifatnya seperti adanya disiplin kerja, disiplin diri dan tanggung jawab, terdapat suasana saling mempercayai, komunikasi yang lancar serta tidak banyak penyelewengan dalam organisasi.

\section{DAFTAR PUSTAKA}

Ahmad, M. 2019. Gagasan tentang Manajemen Pendidikan. Jakarta Timur: LP2AB.

Akhiruddin, K.M. 2015. Lembaga Pendidikan Islam di Nusantara. Tarbiya: Jurnal Ilmu Pendidikan Islam, l(1), 195-219. http://journal.uinsgd.ac.id/index.php/jurnal-tarbiya/article/view/143. 
1313 Manajemen Pengembangan Bahasa Arab di Madrasah Tsanawiyah - Muhammad Rizki Dermawan Saragih, Faisal, Neliwati

DOI: https://doi.org/10.31004/edukatif.v4i1.2162

Al-Fawzan, A.R.B.I. 2015. Idhoat Limuallimi Al-Arobiyyah Lighoiri An-Nathiqina Biha Luminasi (Untuk Guru Bahasa Arab, Untuk Non-Penutur Asli). Riyadh: Fahrosatu Maktabah Al-Malik Fahad AlWathoniyyah Atsnaa An-Nasri.

Aprizal, A.P. 2021. Urgensi Pembelajaran Bahasa Arab dalam Pendidikan Islam. Jurnal Pendidikan Guru, 2(2). https://doi.org/10.47783/jurpendigu.v2i2.232.

Assingkily, M.S. 2021. Metode Penelitian Pendidikan. Yogyakarta: K-Media.

Bafadhol, I. 2017. Lembaga Pendidikan Islam di Indonesia. Edukasi Islami: Jurnal Pendidikan Islam, 6(11). http://jurnal.staialhidayahbogor.ac.id/ei/article/view/95.

Daou, A.F.F. 2011. Language Skills. Riyadh: Al-Rushd Library.

Harahap, A.S. 2018. Metode Pendidikan Islam dalam Perspektif Filsafat Pendidikan Islam. Hikmah, 15(1), 1320. http://e-jurnal.staisumatera-medan.ac.id/index.php/hikmah/article/view/21.

Hermawan, A. 2011. Metodologi Pembelajaran Bahasa Arab. Bandung: PT Remaja Rosdakarya.

Hidayat, R. 2017. Ayat-ayat Al-Qur'an tentang Manajemen Pendidikan Islam. Medan: LPPPI

Iskandarwasid, D.S. 2011. Strategi Pembelajaran Bahasa. Bandung: PT Remaja Rosdakarya.

Kamaluddin, K., et.al. 2010. Etika Manajemen Islam. Bandung: Pustaka Setia.

Mahmood, M.U., \& Zailani, M.A. 2017. Kemahiran Menulis Jumlah Bahasa Arab dalam Kalangan Murid Sekolah Menengah. O-JIE: Online Journal of Islamic Education, 5(1), 20-27. http://adum.um.edu.my/index.php/O-JIE/article/view/5234.

Manshur, U. 2015. Manajemen Program Pelatihan dan Pengembangan Bahasa Arab. Pedagogik: Jurnal Pendidikan, 2(1). http://ejournal.unuja.ac.id/index.php/pedagogik/article/view/103.

Mesiono, M. 2020. Manajemen dalam Perspektif Ayat-ayat Alquran. Medan: Perdana Publishing.

Munief, M., et.al. 2021. Manajemen Pengembangan Kemampuan Bahasa Arab pada Madrasah. Jurnal Pendidikan Indonesia, 2(9), 1563-1571. https://japendi.publikasiindonesia.id/index.php/japendi/article/view/296.

Munir, M.S. 2018. Urgensi Evaluasi Kurikulum Pembelajaran Bahasa Arab di Lembaga Pendidikan. AlHikmah: Jurnal Kependidikan dan Syariah, 6(1), 27-35. http://jurnal.staiba.ac.id/index.php/Al-Hikmah/article/view/52.

Ninoersy, T., et.al. 2019. Manajemen Perencanaan Pembelajaran Bahasa Arab Berbasis Kurikulum 2013 pada SMAN 1 Aceh Barat. Fitrah: Jurnal Kajian Ilmu-ilmu Keislaman, 5(1), 83-102. http://jurnal.iainpadangsidimpuan.ac.id/index.php/F/article/view/1759.

Nurcholis, A. 2015. Kontekstualisasi Manajemen Program Intensive Course Bahasa Arab di IAIN Tulungagung. Prosiding Konferensi Nasional Bahasa Arab, 1(1). http://prosiding.arab-um.com/index.php/konasbara/article/view/9.

Oktarizka, O., Endelta, I., Lestari, R.E., Wita, W., Kuntarto, E., \& Noviyanti, S. 2018. Mengkaji Hakikat dan Filosofi Bahasa. Repository Unja. https://repository.unja.ac.id/6453/.

Pane, A., \& Dasopang, M.D. 2017. Belajar dan Pembelajaran. Fitrah: Jurnal Kajian Ilmu-ilmu Keislaman, 3(2), 333-352. http://jurnal.iain-padangsidimpuan.ac.id/index.php/f/article/view/945.

Pane, A. 2018. Urgensi Bahasa Arab; Bahasa Arab Sebagai Alat Komunikasi Agama Islam. Komunikologi: Jurnal Pengembangan Ilmu Komunikasi dan Sosial, 2(1).

http://jurnal.uinsu.ac.id/index.php/KOMUNIKOLOGI/article/view/5452.

Rachman, F. 2015. Manajemen Organisasi dan Pengorganisasian dalam Perspektif Al-Qur'an dan Hadith. Ulumuna: Jurnal Studi Keislaman, 1(2). http://ejournal.kopertais4.or.id/madura/index.php/ulumuna/article/view/1628. 
1314 Manajemen Pengembangan Bahasa Arab di Madrasah Tsanawiyah - Muhammad Rizki Dermawan Saragih, Faisal, Neliwati

DOI: https://doi.org/10.31004/edukatif.v4i1.2162

Rahman, K. 2018. Perkembangan Lembaga Pendidikan Islam di Indonesia. Tarbiyatuna: Kajian Pendidikan Islam, 2(1), 1-14. http://ejournal.iaiibrahimy.ac.id/index.php/tarbiyatuna/article/view/130.

Rohman, F. 2014. Strategi Pengelolaan Komponen Pembelajaran Bahasa Arab. Arabiyat: Jurnal Pendidikan Bahasa Arab dan Kebahasaaraban, 1(1), 63-78.

http://journal.uinjkt.ac.id/index.php/arabiyat/article/view/1131.

Setyawan, C.E., \& Anwar, K. 2020. Peran Bahasa Arab dalam Pendidikan Islam Sebagai Urgensitas Menghadapi Revolusi Industri 4.0. Lahjah Arabiyah: Jurnal Bahasa Arab dan Pendidikan Bahasa Arab, 1(1), 11-19. https://journal.ibrahimy.ac.id/index.php/Lahjah/article/view/571.

Siagian, S.P. 1997. Sistem Informasi untuk Mengambil Keputusan. Jakarta: Gunung Agung.

Siddik, H. 2016. Hakikat Pendidikan Islam. Al-Riwayah: Jurnal Kependidikan, 8(1), 89-103. https://e-jurnal.iainsorong.ac.id/index.php/Al-Riwayah/article/view/109.

Syafaruddin, S. 2015. Manajemen Organisasi Pendidikan: Perspektif Sains dan Islam. Medan: Perdana Publishing.

Tarigan, H. 2008. Menulis Sebagai Suatu Keterampilan Bahasa. Bandung: Angkasa.

Thoha, M. 2012. Pembelajaran Bahasa Arab dengan Pendekatan Manajemen Berbasis Sekolah. OKARA: Jurnal Bahasa dan Sastra, 6(1). http://ejournal.iainmadura.ac.id/index.php/okara/article/view/420.

Turley, J. 2010. Keterampilan Membaca Cepat. Riyadh: Al-Rushd Library.

Wijaya, M. 2017. Manajemen Pembelajaran Bahasa Arab Sinergi Teori dan Praktik. Al-Tanzim: Jurnal Manajemen Pendidikan Islam, 1(1), 1-18. http://ejournal.unuja.ac.id/index.php/al-tanzim/article/view/24.

Winoto, S. 2020. Dasar-dasar Manajemen Pendidikan. Bandung: LKiS. 